\title{
Adherence Intervention Based on Constructionist Care Approach: The Health Professionals' Perspective
}

\author{
Maria Altenfelder Santos ${ }^{1}$ \\ Maria Ines Battistella Nemes \\ Ana Cristina Arantes Nasser \\ Department of Preventive Medicine of University of Sao Paulo, Sao Paulo, Brazil \\ Cáritas Relva Basso \\ Department of Preventive Medicine of University of Sao Paulo, Sao Paulo, Brazil \\ STD/AIDS Reference and Training Center of State Department of Health, Sao Paulo, Brazil \\ Vera Silvia Facciolla Paiva \\ Department of Social Psychology of University of Sao Paulo, Sao Paulo, Brazil
}

\begin{abstract}
An individual psychosocial intervention geared to improve adherence to antiretroviral therapy. It was designed based on the concept of Care, on the constructionist perspective and on the vulnerability and human rights framework. This intervention was tested as part of a research project and was conducted by three previously trained health professionals in an STD/AIDS reference health facility in Sao Paulo. These three professionals were interviewed, both individually and as a group in order to assess the intervention's feasibility. We described and discussed the contents addressed by them regarding the following themes: training and supervision activities; intervention conducting; impact on professional practice and user care; and future intervention implementation. The interviewees reported that this intervention caused them to reflect on their previous practices regarding HIV healthcare. This promoted a better appreciation of the singularity of each user and also more substantial conversations about aspects of the users' daily life concerning their treatment. They considered that the dialogical and horizontal relationship established during the intervention increased users' participation regarding choices concerning paths to self-care. They reported that one of the main difficulties encountered was related to bonding with some users and highlighted the importance of the fact that the intervention strategies made sense to the people under treatment according to their life circumstances and context. They said they believed in
\end{abstract}

Address: Department of Preventive Medicine, Faculty of Medicine, University of Sao Paulo, Av. Dr. Arnaldo, 455, Cerqueira César, $2^{\text {nd }}$ floor, office no. 2174, Sao Paulo, SP, Brazil 01246-903. E-mail: marialtenfelder@, gmail.com, mibnemes@usp.br, anarantes.nasser@yahoo.com.br, cr_basso@terra.com.br and veroca@usp.br. Acknowledgements: We are grateful to the STD/AIDS Reference and Training Center of Sao Paulo State Department of Health (CRT-DST/AIDS-SP), the institution where our research was performed; and, especially, to the health professionals who participated in the research.

We are also grateful to FAPESP (Sao Paulo Research Foundation), for their financial support to the research projects: "Avaliação de Tecnologias para Melhoria da Adesão do Paciente ao Tratamento Anti-retroviral da AIDS", Call PP-SUS 2006/2007, FAPESP Process no. 2006/61277-6; and "Análise critica de uma intervenção para melhoria da adesão do paciente vivendo com AIDS à terapia antirretroviral”, FAPESP Process no. 2008/08007-6.

We would like to thank Helena Spalic for the English translation.

This paper is based on partial data extracted from the MSc thesis in Social Psychology: Critical analysis of an intervention to improve adherence of the patient living with AIDS to antiretroviral therapy / Maria Altenfelder Santos; advisor: Vera Silvia Facciola Paiva; co-advisor: Maria Ines Battistella Nemes. Psychology Institute of University of São Paulo, São Paulo, 2010. 
the feasibility of future intervention implementation in other health facilities and also pointed the need to involve managers and different professionals during this process.

Keywords: AIDS, psychosocial intervention, human rights, antiretroviral therapy, medication adherence.

\section{Intervenção em Adesão Baseada na Abordagem Construcionista do Cuidado: Perspectiva dos Profissionais de Saúde}

\section{Resumo}

Com base na noção de Cuidado, na perspectiva construcionista e no quadro da vulnerabilidade e dos direitos humanos, foi construída uma intervenção psicossocial individual voltada para a melhoria da adesão ao tratamento antirretroviral. A intervenção foi testada em uma pesquisa realizada em serviço de referência em DST/Aids de São Paulo, conduzida por três profissionais de saúde, previamente capacitadas. Com o objetivo de compreender a factibilidade da intervenção, as três profissionais foram entrevistadas, individualmente e em grupo. Foram descritos e discutidos os conteúdos abordados pelas profissionais, em relação aos seguintes temas: atividades de capacitação e supervisão; condução da intervenção; repercussões para a prática profissional e para o tratamento dos usuários; e implantação futura da intervenção. As entrevistadas relataram que a intervenção estimulou a reflexão sobre suas práticas de cuidado em HIV/Aids, levando-as à maior valorização da singularidade dos usuários e ao aprofundamento da conversa em torno de aspectos da vida cotidiana relacionados ao tratamento. Consideraram que a relação dialógica e horizontal estabelecida na intervenção promoveu maior participação dos usuários na escolha de caminhos para seu autocuidado. Descreveram que as principais dificuldades foram relacionadas à criação de vínculo com alguns usuários e destacaram a importância de as estratégias de intervenção fazerem sentido para a pessoa em tratamento, de acordo com seu momento e contexto de vida. Disseram acreditar na viabilidade da implantação futura da intervenção em outros serviços e apontaram para a necessidade de envolver os gestores e as diferentes categorias profissionais nesse processo.

Palavras-chave: Aids, intervenção psicossocial, direitos humanos, tratamento antirretroviral, adesão à medicação.

\section{Intervención en Adhesión Basada en el Abordaje Construccionista del Cuidado: Perspectiva de los Profesionales de Salud}

\section{Resumen}

Basado en la noción de Cuidado, en la perspectiva construccionista y en el cuadro de la vulnerabilidad y de los derechos humanos, fue construida una intervención psicosocial individual direccionada para la mejoría de la adhesión al tratamiento antirretroviral. La intervención fue testada en una investigación realizada en servicio de referencia en ITS/SIDA en São Paulo, conducida por tres profesionales de salud, previamente capacitadas. Con el objetivo de comprender la factibilidad de la intervención, las tres profesionales fueron entrevistadas, individualmente y en grupo. Fueron descritos y discutidos los contenidos abordados por las profesionales, en relación a los siguientes temas: actividades de capacitación y supervisión; conducción de la intervención; repercusión para la práctica profesional y para el tratamiento de los usuarios; e implantación futura de la intervención. Las entrevistadas relataron que la intervención estimuló la reflexión acerca de sus prácticas de cuidado en VIH/Sida, las llevando a mayor valoración de la singularidad de los usuarios y la profundización del diálogo acerca de aspectos de la vida cotidiana relacionados al tratamiento. Consideraron que la relación dialógica y horizontal establecida en la intervención promovió mayor participación de los usuarios en la elección de caminos para su autocuidado. Describieron que las principales dificultades fueron relacionadas a la creación de vínculo con algunos 
usuarios y destacaron la importancia de las estrategias de intervención hacer sentido para la persona en tratamiento, de acuerdo con su momento y contexto de vida. Dijeron creer en la viabilidad de la implantación futura de la intervención en otros servicios y apuntaron para la necesidad de involucraren los gestores y las diferentes categorías profesionales en ese proceso.

Palabras clave: SIDA, intervención psicosocial, derechos humanos, tratamiento antirretroviral, adhesión a la medicación.

The adherence of people living with HIV to antiretroviral therapy (HAART) is a fundamental aspect of AIDS treatment. The effectiveness of HAART depends on the maintenance of high rates of adherence of people in treatment to the prescribed therapeutic regimens - which is not only essential to individual treatment, but also strongly impacts on the dissemination of the disease on a collective level (Teixeira, Paiva, \& Shimma, 2000).

Since the 1960s investigations on this complex and multifaceted issue sought to measure adherence rates in diverse contexts, employing various methodological strategies, as well as tried to explain the reasons for non-adherence (Caraciolo, 2010; Teixeira et al., 2000). Nonadherence to HAART has been related to two dimensions: characteristics of the person in treatment (such as socioeconomic profile, drug use, comorbidities); and the characteristics of the disease and the treatment itself (such as time of treatment, therapeutic regimen, collateral effects). Brazilian studies also relate adherence to the characteristics of care organization in health facilities (such as availability of resources, access to services, length of time of visits, availability of activities to improve adherence; Teixeira et al., 2000). Studies of the last decade draw attention to the relationship between quality of care and adherence rates to AIDS treatment among people assisted in health facilities (Nemes, 2009; Nemes, Castanheira, et al., 2009).

However, there is no consensus in literature concerning explanations regarding the effectiveness of interventions aiming to improve adherence to antiretroviral therapy just as there is no simple correspondence between employed strategies in interventions and the theoretical bases that support them (Amico, Harman, \& Johnson, 2006; Basso, 2010; Caraciolo, 2010; Dulmen et al., 2007; Munro, Lewin, Swart, \& Volmink,
2007; Rueda et al., 2006; Simoni, Frick, Pantalone, \& Turner, 2003; Simoni, Pearson, Pantalone, Marks, \& Crepaz, 2006).

A large part of the interventions aiming to improve adherence to HAART is based on "behavioral change models" (Bãban \& Crãciun, 2007) implicated in theories on health behaviors (Glanz, Lewis, \& Rimer, 2002). Emphasis is given to the Model of Health Beliefs; the Theory of Rational Action and Planned Behavior; the Social Cognitive Theory; the Self-Regulatory Perspective; the Transtheoretical Model; the Stress and Coping Model; the Social Support Perspective; the Patient-Professional Communication Framework; and the Information, Motivation and Behavioral Abilities Theory (Bãban \& Crãciun, 2007; Dulmen et al., 2007; Glanz et al., 2002; Munro et al., 2007).

Without intending to extend the discussion on these theoretical models, we would like to stress the emphasis they place on the individual dimensions of falling ill, almost never considering the social, inter-subjective and programmatic contexts involved in the treatment that Brazilian epidemiological studies highlighted. Their proposals of intervention in adherence are aimed predominantly at: correcting patients' perceptions or beliefs regarding adherence; modifying attitudes and behaviors regarding treatment; and training patients' new abilities that will facilitate adherence (M. A. Santos, 2010).

This article discusses a proposal for intervention, entitled "Constructionist Care Approach to Adherence" (ACCA) ${ }^{2}$, based on another theoretical field: the notion of "Care"3 (Ayres, 2001, 2004) and a psychosocial approach inspired by

2 Translator's note: ACCA is the acronym for " $A b o r$ dagem Construcionista do Cuidado em Adesão".

3 Care is written in capital letter, according to the proposal of the original author. 
constructionism (Paiva, 2012b), both developed within a human rights-based approach to health that characterized the so called "Brazilian response to AIDS" (Berkman, Garcia, Munoz-Laboy, Paiva, \& Parker, 2005; Gruskin \& Tarantola, 2008; Kalichman \& Diniz, 2009).

\section{Vulnerability and Human Rights Fra- mework (V\&DH): References for Health Practice}

In the past years, in the field of AIDS, the references that integrate the so called "vulnerability and human rights framework" have consolidated the analysis of the dynamics of the epidemic, which substantiates the utter importance of ensuring non-discrimination and, therefore, access to good quality healthcare by people living with HIV. This conceptual framework emerged in the beginning of the 1990s, marking an opposition to the notions of risk groups and behaviors that predominated among the first responses to the advent of the epidemic, producing stigmatization of groups and practices (Mann \& Tarantola, 1996) ${ }^{4}$. This paradigm, employed to think about the health-disease process, aimed to

... respond to the perception that the chance of exposure of people to falling ill from HIV and AIDS is not resultant of a set of individual aspects only, but also of collective, contextual ones, that produce a higher susceptibility to infection and to falling ill, and, in an inseparable way, of higher or lower availability of resources of every kind to protect oneself (Ayres, Calazans, Saletti, \& França, 2006, p. 396). ${ }^{5}$

\footnotetext{
Initially proposed by a group of activists and researchers associated to Harvard University and with a strong presence in the nascent AIDS program of the United Nations (Joint United Nations Program on HIV/AIDS [UNAIDS]), the vulnerability framework was able to develop more firmly in Brazil because the response to the epidemic was parallel to the formulation and construction of SUS (Sistema Único de Saúde), also strongly inspired by the approach to health implicated in the human rights perspective (in the notions of equality, universality, integrality and participation).

5 T. N.: Free translation from the original in Portuguese.
}

This framework is especially connected to the view of health as a right, just like the Care perspective and the social psychology approach in health that integrates Care perspective in Brazil, both of which are heirs of the sanitary and psychiatric reform that, since the 1980s, has substantiated the ethical-political principles of the SUS and replaced the old asylum model (Paiva, 2012b).

The Brazilian constructionist social psychology approach broadened the way to regard the individual dimension of vulnerability proposed by Mann and Tarantola, (1996), defining it as the plan of inter-subjectivity (Ayres, Paiva, \& França, 2011, 2012). That is to say, it substituted the idea of a biological-behavioral individual to be treated in behavioral interventions for the idea of the person as a subject in act, in dialogue, in context, in relation, constantly rebuilt in the interaction with others. Emphasis is given to the plurality of the subject, challenged in his/her daily life by the simultaneous presence of discourses that are often contradictory, socially and historically constructed and interiorized throughout life, in a process mediated by significant others (people or institutions) in charge of his/her socialization. The socialization process (Berger \& Luckmann, 1987) gives meaning to the dynamics of everyday life, which is updated by the subject in every inter-subjective context, in each "scene" lived in his/her daily life (Paiva, 2006, 2007, 2008, 2009, 2012a).

This notion of scene, which is the central focus of analysis and understanding in this constructionist angle, favors the dramatic performance and interactive dimension of inter-subjectivity (inspired by authors such as Goffman, 1975, 1980). Developed in studies on sexual and reproductive health promotion, this notion understands that each inter-subjective "scenario" mobilizes different "scripts" - symbolic systems translated into codes of conduct, composing a repertoire translated into performances in different situations and interactions (Gagnon \& Parker, 1995; Paiva, 2007, 2008, 2012a; Parker \& Aggleton, 1999; Simon \& Gagnon, 1984). In this approach, the concrete and unique experience of the person as a "subject in scene" is the 
unit of analysis and focus of actions in health programs.

Still with regard to individual dimension of vulnerability, which is inextricably implicated on programmatic and social planes (Ayres et al., 2011, 2012; Paiva, Ayres, \& Gruskin, 2010), emphasis is placed on the conception of patient as user of a health action, as a subject of rights or subject-citizen - with a right to information, a right to equity in access to services, a right to integral health attention (Paiva, 2006, 2009, 2012a). Adopted in practices undertaken within SUS and, especially, in the field of HIV/AIDS, this perspective expresses the central importance of values such as: the respect to a right to medication and treatment, a right to secrecy concerning HIV infection diagnosis and a right to autonomy of the person living with HIV to make decisions concerning his/her treatment. Implicated in social and programmatic dimensions of vulnerability and therefore in actions derived from analysis of the health-disease process, this constructionist angle values the authors who analyzed stigmatization processes and discrimination in social interactions and particularly in the dynamics of HIV epidemic (Parker \& Aggleton, 2001). It is understood that differences in gender, color/ race, sexual orientation, class and age are transformed into inequality through discriminatory discursive practices. Therefore, structural and institutional inequalities interfering in everyday experience of living with HIV, in access to available resources and adoption of self-care practices should also be approached on an individual level. On the programmatic level, which is one of the main interests of this paper, availability and quality of resources to be accessed by the person are analyzed, as for example programs and services organized by the different government spheres. On this level, analyses or interventions are not focused only on material investments, but also on the political commitment towards the protection of rights, which should guarantee vulnerability reduction, on action planning, on the evaluation and intersectorial articulation, as well as on strengthening participation and social control mechanisms in all stages (Ayres et al., 2011, 2012; Paiva, 2009, 2012a).
Since they are interdependent, these three vulnerability levels should be addressed jointly in each focused situation. According to this proposal, synthetic analysis of the three dimensions is possible by approaching the "inter-subjectivity in scene" (Ayres et al., 2011, 2012; Paiva, 2009, 2012a), or "the person in context and the context in person" (Paiva, 2012a; Sato, 2005), which are synthetic expressions of the psychosocial dimension. Therefore, in this constructionist approach the concept of psychosocial care, which is rarely defined in literature, gains specific contours since it is integrated to the notion of Care developed by Ayres (2001, 2004).

The proposition of Care attempts to move beyond a model of health attention excessively grounded in the scientific-technological rationality. It emphasizes that health practices also involve another kind of rationality - characterized as practical wisdom and related to life fulfillment or, in other words, to what is desired as a health and happiness project, which is translated in the "exercise of shared choice of a way of life" (Ayres, 2004, p. 586) ${ }^{6}$. It proposes that the "technical success", consolidated in "objects" or "products" of health work (for example, the good clinical outcome of treatment), is not adopted as the only criterion of success (Ayres, 2001). The normative horizon for health practices assessment should also include the notion of "practical success", which expresses processes of "anticipation, choice and negotiation of a good life" (Ayres, 2004, p. 586) 7 developed in the encounters between the health professional and the user. In this encounter between subjects, the communicational, relational and dialogic dimensions, as well as the formative character of this interaction are emphasized, in the sense of rebuilding lifestyles. This dimension cannot be reduced to "a cognitive apprehension such as cause-effect" that considers "the processes and results of every technical component as isolated of the meaning it assumes in the broader tech-

\footnotetext{
T. N.: Free translation from the original in Portuguese.

7 T. N.: Free translation from the original in Portuguese.
} 
nological arrangement in which it is inserted" (Ayres, 2004, p. 589). ${ }^{8}$ As an ethical-philosophical proposal, the Care approach reaffirms the idea that people should not have their last words about their own needs subtracted from them.

In the professional-user encounter, which is the focus of Care as well as a psychosocial dimension always acknowledged in Caring, the user is defined as a specialist - specialized in his own life and in the management of his daily life (Paiva, 2002, 2006, 2012a).

In this psychosocial and constructionist approach, the co-understanding of the meaning people give to their own experience should serve as a starting point (Paiva, 2012a) in an exercise of "coding" and "decoding", as defined by the educator Paulo Freire. This "coding" process, as proposed by Freire to alphabetizing, begins with a sound description and joint interpretation of the meaning of the socially contextualized experience of the person (Paiva, 2006, 2009, 2012a). The exploration of scenes encourages this description with the purpose of increasing the awareness of the person, taken as a subject of discourses he/she has access to (prevention, religious and rights discourses), elevating his/ her repertoire of practices implicated in intersubjective, social-cultural and programmatic scenarios - that is to say, shedding light on the processes of stigmatization, inequality and exercise of rights in his/her everyday experience, which in this case is his/her living with AIDS. ${ }^{9}$ By adopting a perspective of the person as a citizen, a subject of rights, then health care is not regarded any longer as a pre-programmed script and replicable process in any social, personal

T. N.: Free translation from the original in Portuguese.

9 This proposition was named in some texts as Abordagem da Emancipação Psicossocial (Psychosocial Emancipation Approach; Paiva, 2002, 2009) in opposition to the approaches that conceive people as consumers of products and services (receipts, prescriptions), aiming to adequate their actions to predefined behavioral models to be taught, and in opposition to the idea that there is something lacking in them, that should be treated or trained. or programmatic life context. Professionals are trusted to apply their creativity for the continuous reconstruction of strategies of Care grounded in the interactions of professionals and users (Ayres et al., 2011, 2012; Paiva, 2002, 2009, 2012a).

\section{Psychosocial Dimension of Care in the Field of Adherence}

This theoretical field - the vulnerability framework and its ethical-methodological references to health practices conducted in Brazil - is congruent with the analyses of adherence developed within the Brazilian response to AIDS. It also contrasts with the perspective of psychology of health that approaches health behavior to adequate / adapt / correct / train the patient-individual, or just to "treat" him.

Adherence is defined as a complex and dynamic phenomenon (Melchior, Nemes, Alencar, \& Buchalla, 2007; Nemes, 2009), which may be clarified as follows: people are not non-adherent or adherent. They are, in a given moment, following their treatment in an easier or harder way. On the individual plane, what matters is the particular way in which each person gives meaning to his/her treatment, namely, the way the person deals with the disease on everyday basis and with the need to submit himself/herself to continuous use of medication, considering not only the biological aspects, but also the psychosocial dimension of falling ill - with special relevance, in the case of AIDS, to the suffering stemming from the stigmatization processes (Nemes, 2009). As in the psychosocial approach of Care, health practices are analyzed through a comprehensive logic, that always gains meaning in light of an interpretative totality.

The situation that is animated with interest is medication intake, which will assume different meanings for each subject and each inter-subjective context. In other words, whether you take your medications at home or at work is a different thing. Different scenarios include the participation of different "actors" (who can be physically present or just in the imagination of the person): the mother arriving home, the colleague entering the bathroom, or the partner who 
might find the medications in the backpack. In each "scene of medication intake", discourses on the disease or treatment are updated - such as the mystical discourse stating that improvement and cure should come from a divine realm; or the discourse of a physician who insists on the need to take the medications - and the conduct of the subject will express the primacy of one or another discourse in the spontaneity mobilized in every scene.

Attention is paid, thus, to how the subject lives with the treatment, observing the dynamics of medication intake during the everyday interactions that occur in the diverse inter-subjective contexts visited by the person - including the health facility. Therefore, the question is not whether the person "is taking his/her medications correctly", to use a current expression employed by many health professionals when approaching the adherence theme (Teixeira et al., 2000); but rather how the person is taking them and the meanings every medication intake assumes in his/ her experience.

The health facility user is not concerned whether he is following the medical prescription or not, but rather if he is dealing with the treatment in the most convenient way according to his life context, which the notion of practical success allows us to think. In this perspective, the possibility of an instrumental failure of the intervention can be sincerely admitted, of continuing to provide care to someone who, even if interested in care, is not adherent to it - and may possibly never be. It is not a matter of abandoning the work's technical goal, but rather of recognizing that it will make no sense before it is configured as an authentic practical success (Nemes, 2009).

The ACCA proposal is synthetized in the Figure 1, below.

\section{Logic}

\section{Conception of patient}

Comprehension of the psychosocial dimension of adherence

\section{Intervention focus}

Main objectives of the proposed interventions

\section{Main targeted results}

Normative dimension (that guides practice)
Comprehensive: meanings that make themselves present in a contradictory and synchronic way, in every scene or context of the subject's daily life are sought

As a user; an approach of the person based on the notion of integrality; as a plural subject, subject of many discourses to which he/she has access in his/ her socialization; especially as a subject of rights

The person should cope with discourses in dispute, negotiated and updated by the subject in every scene of medication intake, scenes which are crossed by social-cultural and programmatic scenarios, by stigmatization, gender inequality and other contexts of rights violation

To understand the person in scene, the scenes of medication intake and the programmatic encounters for Care, encouraging participation and social control as a user

Decode with the person the meanings and contexts of his/her practices, in scenes and experiences; co-invent new possibilities of interaction in different situations; define "conveniences" and co-build health and happiness projects; suggest action in the programmatic and social dimension of vulnerability to falling ill

Awareness increase among professionals and users regarding their own repertoire and the different contexts of medication intake; improvement in the relationship with the treatment; changes in the field of health programs in order to support decrease in social vulnerability to falling ill

Besides technical success, practical success (communicational, relational, dialogical dimensions); technical success configured as legitimate practical success

Figure 1. Synthesis of the "Constructionist Care Approach to Adherence" (ACCA). 
This article is part of a research project that assessed an intervention designed in the theoretical framework described above and conducted in the STD/AIDS Reference and Training Center of Sao Paulo State Department of Health (CRTDST/AIDS-SP). The research project as a whole focused on the assessment of the effectiveness of the intervention, as well as its feasibility and acceptability, under the viewpoint of the professionals who conducted the intervention and the users of the health facility who participated in the study. ${ }^{10}$ The objective of the present paper is to discuss, from the perspective of health professionals, if ACCA is a feasible approach in the context of public health facilities assisting people living with HIV in Brazil, and if ACCA can be conducted by professionals from different disciplines.

\section{Methods}

In-depth interviews with the professionals who conducted the intervention were done in three stages. Two of the authors of this study who conducted these interviews were not part of the staff of the health facility where this research project was performed, nor did they participate in the empirical conduction of the research-intervention or know the professionals or users participating in this intervention. All the interviews were magnetically recorded and transcribed.

In the first stage, the individual interviews employed a script of 17 open-ended questions that addressed the following points: the difficulties and ease professionals identified throughout the training and intervention activities; repercussions this experience had on their practice in the field of AIDS and, especially, on the care intended to improve adherence; potentials and limits of this proposal to assist people living with HIV

10 Other analyses currently in progress were also done by researchers who did not participate in the process of planning and conducting the intervention, focusing on the perspective of users who participated in the intervention and on the analysis of the interaction that occurred during the encounters, which were recorded magnetically (discussed by Bellenzani \& Nemes, in this volume). to find ways to live better with their treatment; and challenges to a future incorporation of the intervention in other health facilities. The second stage, a group interview with the same script, led to further deepening by raising differences and similarities in how each one of them experienced the process. In the third stage, a new round of individual interviews was conducted that provided detailed description of encounters with some of the participants as well as examples of situations experienced in these cases. The script proposed that two cases of people seen in the research process of intervention were chosen, one that they considered successful and another unsuccessful. Afterwards, they were asked to briefly relate their experience in conducting encounters with the selected participants and to explain the criteria adopted for characterization of "success" or "failure" of these cases. Two of the professionals chose to add a third case, described by them as "intermediate" in what concerned success, thus totalizing eight cases elected.

In the analysis, the content of the interviews transcribed audio material was analyzed based on the previously established themes: training activities, supervision sessions, conducting of the encounters, repercussions of this approach on professional practice, perceived benefits to participants, and future implementation of this intervention in the health facilities.

In this content analysis, similarities and differences were sought in the speeches of the professionals and between the stages. The speeches quoted in this text were identified with fictional names - Marina (social worker), Joana (psychologist working in the health assistance area) and Renata (psychologist working in the prevention and management areas) - followed by acronyms indicating whether the passages were taken from individual interviews (I. I.) or from collective interview (C. I.). The passages were chosen only to illustrate the analysis, having no equal number of quotes by each of the three professionals.

So, we promoted a debate around the speeches presented, recovering former experiences grounded in the same theoretical referential that gave basis to the intervention. We did not approach, in this discussion, the intervention effecti- 
veness dimension, i.e., the results of the clinical trial that assessed it (see below).

The present study, as well as the original research project, are in accordance with the guidelines and norms of the research projects involving human beings (Resolution 196/1996 of the National Health Council) and were approved by the Research Ethics Committee of CRT-DST/ AIDS-SP. The participating professionals and users were previously informed of the objectives of the investigation, they agreed to participate in it, read and signed the Informed Consent Term, and had their identities preserved.

\section{Intervention Process Synthesis}

Experiences in health promotion actions adopting this approach were compiled mainly in the field of sexual and reproductive health. The ACCA proposal adapted the same referential for individual intervention to improve adherence.

This research project was motivated by the need, perceived by the STD/AIDS State Program of Sao Paulo and pointed out in former studies conducted by the Qualiaids Team ${ }^{11}$, to increase knowledge on adherence-focused activities, which are a part of the routine of AIDS health facilities in the state of Sao Paulo. This research project was conducted by the partnership formed by the two groups. The first phase described activities concerning improvement of adherence in the health facilities of SUS (Caraciolo, 2010; Caraciolo et al., 2009). The second phase, which will be discussed later in this work, built and tested the potentially effective model of intervention to improve the way people with HIV live with their treatment (Nemes, Qualiaids Team, \& CRT-DST/AIDS-SP, 2009).

The ACCA model construction was based on the academic and practical experience of the research team members, on the national and international literature review on adherence interventions, and on a workshop with professionals experienced in conducting adherence activities in the Sao Paulo state health facilities as well as renowned professionals and academics with

${ }_{11}$ About the Qualiaids team, access: www.qualiaids.blogspot.com a wide experience in the field of AIDS, fully embodying the vulnerability and human rights framework.

An individual intervention protocol design was then tested in a pragmatic clinical trial (Basso, 2010; Basso, Santa-Helena, Caraciolo, Paiva, \& Nemes, 2012) conducted in 2008 in the CRT-DST/AIDS-SP. The participants in the study were users over 18 , undergoing the same antiretroviral regimen for at least six months, with detectable viral load ( $>50$ copies $/ \mathrm{ml})$ in the 120 days prior to being recruited, randomized into two groups of intervention and control. Both received the usual health facility care. The intervention-group participants were invited to participate in four individual encounters with a health professional (synthetized in Table 1). Adherence measures (obtained by an electronic monitoring system of medication intake) and viral load measures of both groups were compared during the six month period of follow-up.

By the end of the four meetings, the professional and the user were expected to begin a consistent self-care plan, being aware of the limits and possibilities at stake and identifying the various forms of support available to the user at the health facility.

Three health professionals out of ten candidates participating in the training activities were selected to conduct the intervention under the following criteria: full understanding and uptake, acceptance and adoption of the proposed approach; ability to establish communication based on dialogue, active listening and encouragement of the users' participation; ability to act as a multiplier of the tested intervention model in case it showed effectiveness; availability to participate in the project's meetings; and commitment through attendance and punctuality in the implementation of the activities.

The training process was based on the problematizing methodology developed by Paulo Freire (1987) and included experiences and discussions where the professionals were invited to dialogue with their own concepts, values and practices, revisiting them in light of the ACCA referential. For example, there was an experience where professionals ran a medication intake sim- 
ulation for 48 hours using placebos, according to the users' routine; and role-playing interventions with professional actors or colleagues acting as users. At the end of the training session, the professionals performed a pilot of the intervention together with volunteers who did not participate in the intervention phase of the research project.

The intervention aimed at deepening the dialogue about difficulties in medication intake, starting with examining the meanings the treatment assumes in the person's general life context and identifying scenes in his/her narrative which would express these meanings more concretely; or encouraging the production of scenes by the user, exploring scenes lived or imagined by him/her, i.e., exercising his/her active imagination ${ }^{12}$ and, possibly, role-playing it. The activity addressed during the training may be developed with people sitting naturally in the outpatient facility's chairs, deepening their conversation through case reporting, with vivid speeches and active imagination. As proposed by Paiva $(2005,2012 a)$, the professional's task is to lead the user into describing his daily life situations as richly as possible, identifying the contexts in which they occur and the characters present (relatives, friends, partners, health professionals, work colleagues, boss, other people with HIV, etc.) bringing forth their different speeches and the meanings of each speech or action. The scene exploration from various perspectives encourages the person to reinvent ways to conduct the scene. The professional acts as a director: asking for clarification concerning scenarios - the stage (place) where the action is performed and its social context - and the roles played; and often requesting that parts of the scene be replayed, roles exchanged, the stage extended into a broader social, cultural, economic and institutional scenario, etc. After fully explor-

12 The term "active imagination" was coined by C. G. Jung to name the method in which he proposed that the subject concentrated in a situation, image or specific event, triggering off, from this initial point a succession of images which would gradually gain details and movement, acquiring a life of its own (Jung, 1985). ing the scene, professional and user talk about the elements that emerged from this exercise, such as: the recovery of the situations reported and the realization of how these happened; what their broader context is; what new meanings can be attributed to them; and what new ways and solutions can be devised to deal with these difficulties.

The encounters were recorded in two different tools: a form to be filled at the end of every conversation whose content was agreed upon between professional and user contributing to the process of pact forming around the issues discussed and therefore characterized as a component of intervention; and an individual tool through which professionals briefly related the previous encounter, recording their impressions and difficulties in conducting the session.

Considering the innovative characteristic of the proposed approach, as well as the need to achieve a degree of homogeneity in the execution of the intervention that could sustain a pragmatic clinical trial and the critical reflection about the process, the protocol included collective supervision sessions to the professionals. The sessions were conducted by physicians who integrated the research team as well as by a psychologist with experience in using the scenes methodology in the field of AIDS.

\section{Results and Discussion}

In general, the professionals appreciated the opportunity to participate in the research project and indicated that the experience brought them noticeable repercussions on their professional practice, beyond adherence to antiretroviral treatment. According to the declarations by the three interviewees, the proposal of ACCA has an innovative character and the potential to encourage healthcare professionals to review and transform their practices in the sense of prioritizing the perspective of the user as well as deepening the conversation by approaching his life context. It is worth highlighting that the three professionals had a wide experience in the field, having spent over 15 years working in that place. 
Table 1

Objectives and Structure of the ACCA Intervention*

\begin{tabular}{|c|c|c|c|}
\hline & Session 1 & Sessions 2 and 3 & Session 4 \\
\hline Objectives & $\begin{array}{l}\text { Contract; } \\
\text { Identify situations ant } \\
\text { contexts of daily life } \\
\text { that are obstacles for } \\
\text { treatment; } \\
\text { Organize priority issues } \\
\text { and decide on themes } \\
\text { to be part of next } \\
\text { conversations; } \\
\text { Clarify most technical } \\
\text { question about } \\
\text { treatment. }\end{array}$ & $\begin{array}{l}\text { Increase knowledge about treatment; } \\
\text { Understand and decodify real life } \\
\text { scenes; } \\
\text { Amplify daily scene to bigger } \\
\text { programmatic and social context; } \\
\text { Foster creative and active } \\
\text { imagination about daily life; } \\
\text { Foster new personal repertoires } \\
\text { to face identified obstacles to } \\
\text { treatment. }\end{array}$ & $\begin{array}{l}\text { Deeper understanding of } \\
\text { feasible and desired changes } \\
\text { in context and personal } \\
\text { conduct aiming at self- } \\
\text { care and enhancement of } \\
\text { patient-clinic quality of } \\
\text { communication and care; } \\
\text { Identify resources to pursue } \\
\text { and sustain chosen paths to } \\
\text { face difficulties with ARV } \\
\text { treatment; } \\
\text { Close the process. }\end{array}$ \\
\hline Themes & $\begin{array}{l}\text { Mutual recognition } \\
\text { of patient as experts } \\
\text { on daily life and } \\
\text { professionals- } \\
\text { researchers as technical } \\
\text { experts; } \\
\text { The overview of the } \\
\text { patients' social and } \\
\text { inter-subjective context; } \\
\text { Questions about the } \\
\text { treatment. }\end{array}$ & $\begin{array}{l}\text { Questions about treatment; } \\
\text { Real episodes where treatment is } \\
\text { not followed; } \\
\text { Paths to face obstacle and "in } \\
\text { scene" solutions. }\end{array}$ & $\begin{array}{l}\text { Questions about treatment; } \\
\text { Reviewing paths, solutions } \\
\text { and repertoires; } \\
\text { Talking about how to } \\
\text { face future obstacle and } \\
\text { difficulties and sustain } \\
\text { changes; } \\
\text { Final clarifications and } \\
\text { orientations on the research } \\
\text { process. }\end{array}$ \\
\hline Methodology & $\begin{array}{l}\text { Talking about the } \\
\text { procedures, aims and } \\
\text { contract; } \\
\text { Free conversation and } \\
\text { careful listening about } \\
\text { the person's life; } \\
\text { Focus questions about } \\
\text { treatment and on } \\
\text { situations and episodes } \\
\text { where following } \\
\text { treatment is difficult; } \\
\text { Use of informative } \\
\text { resources (folders, } \\
\text { guidelines, adherence } \\
\text { kits); } \\
\text { Record specific } \\
\text { situations and episodes } \\
\text { that seem to be more } \\
\text { important to cope on a } \\
\text { recording sheet. }\end{array}$ & $\begin{array}{l}\text { Reviewing contract and questions; } \\
\text { Looking at typical episodes of } \\
\text { non-adherence; } \\
\text { The participant chooses his priorities } \\
\text { from a list of problems; } \\
\text { Taking and exploring scenes from } \\
\text { real episodes; } \\
\text { Decoding the scenes, and through } \\
\text { active imagination and role-playing } \\
\text { reinvent them; } \\
\text { Talking about obstacles that are } \\
\text { beyond individual action, and } \\
\text { shared by other people living with } \\
\text { HIV; } \\
\text { Discussing individual and } \\
\text { programmatic resources; } \\
\text { Professional and participant record } \\
\text { and organizing a hierarchy of scenes } \\
\text { and situations on recording sheets. }\end{array}$ & $\begin{array}{l}\text { Reviewing contract and } \\
\text { questions; } \\
\text { Taking and exploring scenes } \\
\text { from real episodes; } \\
\text { Decoding the scenes, and } \\
\text { through active imagination } \\
\text { and role-playing reinvent } \\
\text { them; } \\
\text { Inform on social and } \\
\text { programmatic resources, as } \\
\text { well as constitutional rights; } \\
\text { Recording decisions and } \\
\text { plans for the future on } \\
\text { recording sheets. }\end{array}$ \\
\hline
\end{tabular}

Note. *Table extracted from Basso et al., 2012. 


\section{Training and Supervision}

From training, practice transformation was highlighted:

I was very insecure, I even thought that I wouldn't be able to handle it. . . . Because ... for 15 years you assist users in a given way, then it was as if I had to deconstruct everything I had learned before and start it all over again. (Marina, I. I.)

The interviewees pointed out that the process of deconstruction of practice - especially the revision of a predetermined working model, which does not value dialogue irrespective of the singularity of the user - is a real challenge to be faced in the implementation of this model in other health facilities. In the specific case of the institution where this research project was undertaken, they considered that ownership of the notions proposed by ACCA was facilitated because they were work principles already disseminated in CRT-DST/AIDS-SP, which is not the same in the majority of health facilities.

In this regard, the interviewees emphasized that promoting critical reflection of the professionals on the usual practices would be a fundamental step in training activities, and that higher investments in this initial step would be necessary to mobilize the professionals to get in touch with possible new forms of practicing: "I think we won't change the professionals, but we expect them to see the limitations of their practice" (Renata, C. I.).

They also stressed the importance of supervision to complement training learning. They found it was important to have physicians as supervisors. The interlocution between different scopes of knowledge (medicine, psychology and social work) was essential for them to improve dialogue with users about issues related to the use of medications - including aspects of the treatment which normally belong to the medical field.

At the same time, since the intervention is based on the idea of prioritizing the perspective of the user, the interviewees appreciated the approach of addressing issues that were not directly related to medication intake. One of the topics discussed during the supervision was the difficulty faced by the professionals during several encounters to focus the conversation on adherence. Thus, it was recognized that there are situations where it is necessary to put aside the issue of medications in order to prioritize spontaneous demand of the user so that the topic of adherence may be subsequently revisited in a more integrated way according to his life context, a situation exemplified in Joana's speech:

This is the case of a woman ... very dependent on her daughter . . . who lives . . in the same backyard. . . The married daughter had a one-year old baby ... she [the participant] came here in pieces . . . because this daughter was moving to the northeast; and even if I wanted to direct the conversation . . towards our proposal, she brought these issues. Then I . . let it flow . . I remember she told me like this: "Look. . . I don't want to talk, I just want to get out of here. I'm feeling very bad". I said: "All right, it's your right". I respected ... then she opened up. ... she told me that she had beaten the baby... grabbed the shoe and hit him in the head. She was feeling very guilty... was in a depression process. . . she was very angry with her ex-husband, who transmitted $H I V . .$. Then it was very nice because . . . she brought all the issues... So much so that in the other encounter we could recover everything that had actually to do with her history . . . And [the] medication ... . she related a lot with affection, if she is not in good terms with her daughter she won't take it. (Joana, I. I.)

By acknowledging this need, the professionals assumed ownership of the proposal of a dialogic posture, sensible to the needs of the user at every moment.

Supported by the supervision sessions, professionals progressively acquired greater autonomy in leading the conversations by realizing that there was no need to follow rigidly the intervention script proposed in the training, thereby respecting the singularity of every interaction:

every situation is a new situation, so the difficulty I had in the beginning was that I wanted to apply what we learned, the way we learned it . . . but there are moments 
when it doesn't have to be exactly that way ... and this I learned in the supervision. (Marina, E. I.)

Without failing to consider that the context of this research study demanded minimal standardization of the intervention format, the professionals indicated aspects of the protocol that could be more flexible in future implementation: the total number of encounters and the duration of each encounter, to be reduced or extended according to the relationship established with each user. At the same time, they found it interesting that there is a previously defined period of intervention, defining " a beginning, a middle and an end" (Renata, I. I.).

They also emphasized the role of supervision in increasing their understanding of possible ways of exploring scenes of daily life with users, which helped them to understand that the strategy was not restricted to the employment of the role-playing resource:

in the beginning . . . there was a big expectation ... on my part to work on the scene, but the role-played scene . . in the supervision ...we ... identified... that . . the fact that the person tells... what happened in her life ... is already an experience of the scene. (Marina, E. I.)

It is important to point out that, in the ACCA proposal, methodology of scenes is not expected to be introduced artificially, but only as far as it can help the professional to get closer to the experience of the user. The idea is to integrate into this approach other tools and practices originated from the professional training.

\section{Conduction of the Encounters}

According to the interviews, the scenes resource enriched the conversation about ways of living with the treatment as well as contributed for the users to present new elements in their speeches concerning difficulties in everyday life, and reformulate their initial questions. It allowed for a dialogue beyond the ready solutions and consolidated discourses, which are usually employed in conversations about adherence. An account concerning encounters with a participant who from the very first encounter expressed difficulties in taking medications correctly due to absence of a routine in his daily life, was expressive. The professional tried to find an hour of the day when he would be awake every day that could be established as a routine for the intake of his medications. In the third encounter, she proposed the dramatic exploration of a medication intake scene at the hour he usually left home for work:

"Ok then, 11:00pm, why don't you take your medication?" / "Oh, because I wake up late and forget to pick up the medication". I say: ". . . do the scene of you waking up late". Then he wakes up late. . . Gets the briefcase, gets the cellphone, then comes the question: "Why do you remember to get the cellphone, but you don't remember to get the medicine?" Then he stops to reflect. . . with my comments: "What can make you remember the medicine?". . . he can't think, then I suggest: ". . . Put a note on the door, then". He wrote a note . . he had a breakdown at that moment, started to cry, static, he couldn't move... I had to get up, hug him, ask him if he was scared: "Let's talk about your feeling". He did not want to talk ... then ... after some 15 minutes like this, in this situation ... he . . calms down ... Then he tells me that he doesn't know what he feels in this moment, that he can't identify what his feeling is, if it's . . sadness, if it's fear, if it's anger because he has HIV. . . we, together ... could realize that the issue of his not taking the medication isn't . . a matter of being late ... He has to discover what this issue is . . that he identified as important . . . and he is going to work it in therapy. (Marina, C. I.)

For the professional, the experience of the scene provided, in this case "another understanding of his situation . . . it was very important because it made him realize that the issue. . . was not outside, was inside himself" (Marina, I. I.). That is to say, from the exercise, new aspects concerning his difficulty were identified and it became clear, even though they did not name it at this moment, the need to give continuity to some assistance where he could work further on these issues. 
According to the interviewees, some aspects concerning decisions of whether or not to use the scenes resource proved relevant: the availability of the participant in every encounter, to approach issues regarding his daily life and to reflect on his way of living with the treatment; the establishment of a bond between professional and user resulting in openness from both sides towards further dialogue; and the possibility that this resource made sense to the user, according to his repertoire, his trajectory and his life circumstances. They observed, for example, that many people made use of the scenes in a spontaneous way in the conversation with a case narrative, bringing examples of concrete situations. In these encounters, the acting-out resource to extend the conversation and to make the decoding of scenes more explicit to the user proved interesting.

However, in some cases the employment of this strategy was not possible. In a case mentioned by The professional, the establishment of empathy was compromised due to an ironic and provocative attitude of the participant from the very first encounter: "everything you did ... she .. . shattered and destroyed . . it was difficult to deal with her... She was an extremely reluctant ... I think she enjoyed provoking" (Joana, I. I.). Moreover, characteristics of the sociocultural context, or specific situations such as depression or recent disclosure of diagnostic, were also perceived by professionals as obstacles to the creation of bonds and, therefore, to the development of an interactive process.

The difficulty in overcoming cultural differences was exemplified by a case with an Asian participant. The professional attributed the impossibility of creating a bond with him to the difficult communication:

you could realize that there was a code there during the conversation ... I don't know if it was someone who understood more what it is like to be a Japanese. . . [it is] a very specific way of communicating. . . you don't know . . . in nonverbal language too, what is it that the person is expressing. . . There was a distance between us that I don't think could be overcome. . . . The four encounters were not enough to achieve the same level of closeness we did with the other patients. .

. concerning complicity within the process, building a bond. (Renata, I. I.)

In another unsuccessful effort to explore scenes, according to the professional, the participant "didn't see any sense in what he was doing" (Marina, I. I.). In this case, the professional also observed that he seemed to be depressed and, among other related difficulties concerning his life contexts, he seemed to be extremely mobilized by recent disclosure of the HIV diagnostic. The professional attributed the "failure" of this encounter to the fact he was "unavailable to any kind of success" (Marina, I. I.).

The higher level of instruction was also mentioned as a possible facilitating element to the understanding of the scenes resource in the case of a person who had "a nice schooling" (Renata, I. I.) and that "from the very first moment ... adhered to the proposal" (Renata, I. I.).

To her [the participant] the scenes thing made sense ... we could do some nice scenes... She got up from the chair, looked at herself in this encounter... She got really emotional with that, then she reflected about it, worked it out ... then she brings this up again as something very important. (Renata, I. I.)

On the other hand, breaking with prejudgments and better appreciating the singularity of the users was emphasized by the interviewees as fundamental contributions of ACCA to the psychosocial dimension of Care, highly stressed in the accounts of the professional who works in the social work field. She refers to her experience in this research as follows: "It changed ... my vision of assistance to the user. . . Because I always mobilized my repertoire to be used in another way" (Marina, I. I.). The professional used the case of a transvestite of whom she had followed-up on at the health facility as an example:

I saw her for. . . five years . . stopped seeing her and then saw her again in this research.... in the first and second encounter she told me already: "Wow, Marina! It's about time this conversation happened, isn't it?" I replied: "Indeed . . I saw you 
for so many years and it took so long for us to have a conversation like the one we had today". (Marina, I. I.)

The quality leap in this case approach originated from life history recovery and a deeper understanding of the difficulties faced in living with the treatment daily. The interviewee compared this posture with the perspective usually adopted by professionals in their "dialogue" with users, which she exemplified below:

"You're not taking medications? . . you have to take it on time, you see? . . And why don't you take it?" / "Oh! I forget". /. . . "you have to get yourself a watch." / "All right, I will do it". . . "Look, you can't use drugs. You have to look for a treatment to stop using drugs. . . . So you . . . will look for that place?" / "Oh! All right, I will". . .. It's different from working according to the perception of the user: "No, actually I don't take the medications properly, it's not only because I use drugs, it's for many other reasons". And you approach these issues and discuss them in another way. Because it's easy for the professional, you identify the difficulty and refer him: "Oh! So go to psychology ... go to the psychiatry". .. . Now, you and the user, to recognize what he is bringing to you, the whole of it - it's essential. I think this process is fantastic". (Marina, I. I.)

\section{Repercussions on Professional Practice}

According to the social worker, social service practice rarely prioritizes the perspective of the user: "When seeing the user, we already kind of have something in mind as to where. . . to refer him to ... as if we have already dealt with that situation he is bringing up" (Marina, C. I.). The interviewee emphasized that the solutions sought during the interaction are frequently based on prejudgments regarding the profile of each population, guided by "group issues" and "epidemiological data", which usually lead to thoughts such as: "how . . the transvestite groups deal with this situation" (Marina, C. I.). According to the professional, this happens to the detriment of the singularity of the person who is actually being seen: "we can't stick only to these indicators alone. . . sometimes, that transvestite has a completely different characteristic" (Marina, C. I.).

The need to overcome consolidated discourses regarding adherence was also emphasized. In another case, the social worker noticed that the person enjoyed great support of her relatives concerning her treatment, and even though this information might have seemed enough in a first moment, in this case in depth understanding of what this relationship was really like proved crucial:

We find it good that the family helps ... but in her case, they helped too much ... Kept reminding her to take the medicine every hour... She wanted to stick to this role... . Actually, she was too comfortable with this situation. (Marina, I. I.)

The interviewee observed that, although aspects related to the treatment as well as to the life context of users are usually approached during visits, rarely are they discussed in an integrated way, based on a scene and a situation:

normally we ... discuss HIV, but not in the daily life of the user. . . we even bring this life context... these issues to the surface, but ... We don't discuss... It's as if one thing was not part of the other. (Marina, I. I.)

The concept of convenience ${ }^{13}$ of treatment was a resource appreciated by the interviewees in operationalizing the ACCA approach, and regarded as a simple formulation capable of guiding the actions of the professional. One of the interviewees working in the management area said that the concept of convenience and the scenes resource were incorporated in her practice involving training other professionals:

It's not enough that you listen . . that you identify the needs [of the people assisted], and what are you going to do with this? So, now I have a tool ... the technique of brin-

13 The concept of convenience encompasses the idea of prioritizing, in the encounter between professional and user, that which is convenient to the user, regarding his life context and his daily life. It is related to the notion of "happiness projects", defined by Ayres (2004). 
ging it to a concrete level, it's possible for everyone to understand and people [health professionals] get more relieved because they know what they have to do, how this happens in the relationship ... my speech grew in maturity. . . because when time came ... I knew what I wanted to say, but I didn't have tools to offer people in a quick, objective way; where they should get to ... what is the goal of this work. Before, it was a vague thing... Now it's not, you say like this ... "let's work on: what is convenience? What is the focus? ... And then what do you do with this? You have 15, 20 minutes, how do you do this?" (Renata, C. I.)

Another point that indicated the incorporation of the ACCA referential by the professionals relates to changes in the concept of success or failure of encounters, implicated in the notion of Care. We noticed that their assessment of cases was not restricted to technical success dimension; they actually considered success from the viewpoint of the user. In this regard, it is relevant to observe that during the interviews the professionals spontaneously opted to include intermediate cases, i.e., to include examples which were successful from the viewpoint of the communicational dimension, taking into consideration the perspective of the user, which did not necessarily lead to adherence increase.

The incorporation of the notion of practical success by the professionals allowed them to accept decisions made by users who, in extreme cases, explicitly objected to technical success. That was the case of a person who used to take an injectable medication (T20), whose daily application represented great difficulty, leaving marks and sore spots in the body. Throughout the process, he even clarified his doubts with the nurse and visited a group with users taking T20, but the difficulty remained. He decided, therefore, that he would not use it as prescribed by the physician. The professional warned him of the risks of taking medication erratically, concluding that in the end "he neither stopped nor took it correctly, he didn't see the possibility to overcome this difficulty . . a complete technical failure" (Renata, I. I.). She did understand, thou$\mathrm{gh}$, that there was a practical success in this case: for that human being, it will never be convenient to take the T20, he made that decision. He did not come to an agreement between who he is and how he lives, what he expects from life, and what this medication demands from him. ... From a traditional viewpoint, we failed because he said that he wouldn't take the medicine anymore. From the existential viewpoint, to this subject ${ }^{14}$. . . he is capable of telling me: "This which you want to offer me is not possible to conciliate with who I am. I'm peaceful, if dying is the price to pay, I'll die, but I just can't do it. Right now, there's no deal'. With this concept, we did not fail. . . Because we offered the guy every possible tool, information, alternatives so that he could get to this conclusion in a less conflicting way. Of course part of him may be afraid of dying, but we opened a space for a speech we would not have before. . . Of [his] telling us: "I won't do it. Please, listen without judging me. I can't do this, I don't want to". (Renata, C. I.)

It is interesting to notice the expression "human being" and "subject" in this speech, expressing a concept coherent with this intervention framework. Far from not being a dilemma for the professional, this case offered her the possibility of understanding and sharing meanings of life with the user that go beyond the patterns established and pursued by health professionals.

\section{Benefits to Users}

Generally speaking, the interviewees saw several repercussions brought by this intervention on treatment. The improvement in the relationship with treatment could be observed in many cases:

there are many accounts . . of people who talk about changes: "Oh! I couldn't swallow the pill and now I can", "I couldn't take the pill outside home for fear of getting sick and now I can take it". (Renata, I. I.)

They observed gains which went from assuming ownership of treatment handling to witnessing transformations occurred in the life

14 T. N.: "subject" meaning "person". 
context of the users, such as a person who stated she often postponed medication intake due to her busy work routine, for example. The encounters supported her decision to quit her job in order to take care of herself and her health:

I don't recall if it was in the second or in the third [encounter] that she came here and said ". . I made a decision. I quit my job" ... She has a pension from her husband. . . the son is already graduated. . . has his own house... has a relatively... stable life, they came to the conclusion she could afford to resign to take care of herself. . . . She had a check-up . . . was seen by many professionals here... scheduled the ear, nose and throat doctor . . orthopedics . . . psychology ... By attending encounters she realized that she wasn't looking at herself and this she now could do. I think her self-perception emerged and she started to take care of herself. (Joana, I. I.)

Improvement of access to resources offered by the institution was another important consequence of the intervention appreciated by the professionals. The interviewees considered that, "from the point of view of the relationship of these patients with the institution, the intervention brought a new possibility" (Renata, I. I.), promoting new ways of assuming ownership of available Care. The dialogic and horizontal character of the relationship established during the encounters proved essential to place the user as a subject of rights, co-responsible for the course of his/her own treatment. The interviewees found that this interaction was distinguished from a relationship of authority usually established with the physician, in which the user hardly questions the prescription of treatment in order to better adjust it to his quotidian:

I think that this is also a part of the treatment ... if we could shake up a little in their heads [participants] this authority issue, if they could then arrive feeling more at ease, in the sense of being able to talk freely, expressing their opinions during the visit . . . aware of the fact they have rights . . . seeing themselves in a space that belongs to them and not to that professional, which is theirs, it's their life, they're the ones who are at stake there. (Renata, I. I.)

According to the professionals, the research also generated some already "worn out" relationships (Renata, I. I.) between physicians and users:

I think that sometimes there's a fatigue, there is nothing more to give, the person [the professional] is worn out and so is the patient; in that relationship, both say: "It's all right" / "It's all right" . . those are dead relationships. (Renata, I. I.)

The intervention allowed for recovery of cases where professionals seemed to have stopped believing in the possibility of advancements:

Ifelt in the speech of the users that the physicians . . . have a great expectation regarding this research project, because the patient who's here . . . is the same that gives him a hard time during visits. (Marina, I. I.) Regarding the role of the institution, the interviewees emphasized the importance of offering services focusing the adherence theme. In the professionals' viewpoint, the simple fact that participants were contacted by the health facility during the research project - which they felt as institutional care - was enough to promote transformations in how they dealt with treatment. They pointed out, however, the need to offer continuous support in order to guarantee long term achievements, given the dynamic character of adherence to treatment. This aspect was illustrated by an interviewee while making up the users' speech:

Now I'm all right, I won't take the medication. Now I'm ill, so I'm going to start taking the medication. Oh! But now I have a lot of things to do in my life, so I'm not able to take the medication properly. (Marina, I. I.) According to the interviewees, the intervention also pointed out the need to offer specific actions to users considered adherent, or to those who do not miss visits, yet do not show improvement in clinical treatment outcomes - conditions frequently overlooked by the institution:

I think we work a lot with adherence with that patient who says: "No, I don't take the medication. I don't want to take the medi- 
cation"... . Now, this patient who says: . . . "I'm taking it" . . . We don't invest in. (Marina, I. I.)

\section{Implementation in Health Facilities}

The interviewees believe in the feasibility of intervention implementation in other public health facilities, but pointed out that these actions need to be part of a workflow in the institution to ensure involvement of professionals in this process as well as the management support: "it's not useful ... to teach professionals to do one thing if the health facility is not moving towards improving its quality" (Renata, C. I.). The introduction of this model of intervention in the health facility would especially challenge the fragmentation of treatment among the different specialties, as illustrated by the speech of one of the participants during encounters, quoted by the professional: "With the physician I treat one thing, with the psychologist another, and this was the only place I combined both things" (Renata, C. I.).

The interviewees emphasized the interdisciplinary character of the intervention because, besides proposing a dialogue between different scopes of knowledge, ACCA also offers tools that can be employed by all professional categories - features that are not always appreciated in the work routine of health facilities:

the social worker and the psychologist are not easily motivated to study the issue of medications. A physician, however, is resistant to studying that which is not exactly the clinical approach to the case. The nurse has a pragmatic vision of things, so she is many times reluctant to taking into consideration the social and psychological issues, therefore each one of them values their own core. (Renata, C. I.)

They emphasized the need, in a future implementation, to work together with the whole team ... to include in the training the perception of where this activity is situated, and the understanding that it serves the patient, it doesn't serve the professional. . . . identify adherence as an inter [disciplinary] field (Renata, C. I.).
Finally, the professionals praised the recording tool, which was jointly filled, characterizing it as a useful strategy to share issues discussed during visits not only by professional and user, but also among the team of professionals responsible for his Care:

Anyone [professional] who's going to see that person [user] brings that material, it is going to enrich it. And if agreed with the patient that it could be a part of the patient record, everybody can access... in the end, that difficulty is shared, discussed by a lot of people... from the team that sees that person. I mean, you do the intervention, but I can also talk about that subject (Renata, C. I.).

\section{Conclusions}

In short, from the standpoint of the professionals who conducted the intervention, ACCA was shown to be a feasible approach in the SUS context; its reproduction possible by professionals of different categories; capable of improving the way people live with their treatment; and with the potential of innovating professional practice in the sphere of healthcare to people living with HIV. The accounts of the professionals also drew attention to aspects of the proposal of intervention to be reviewed and/or emphasized in a future implementation of ACCA.

Among the contributions of this approach to practice, professionals highlighted the ideas of prioritizing the perspective of the user and deepening the conversation concerning his everyday life. From this proposition, the relationship of each person with their treatment could be co-understood in a singular way and actualized in the many inter-subjective contexts, leading to a rupture with pre-conceptions and stereotypes regarding supposed profiles of the "adherent-type patient" or the "non-adherent-type" ones. The notion of convenience and of participation of users in choosing paths to their self-care also allowed for the construction of new parameters of success to professional performance.

The dialogic interaction mode which, together with the users, expands the scene of intake 
and visit into a social and programmatic context, made it possible to situate them as subjects of rights, cherishing this discourse which has evident programmatic and social repercussions. Many programmatic benefits to treatment were indicated by the interviewees: the possibility of a better use of the services offered by the institution; the reflections surrounding the need of the health facilities to organize continuous services to discuss the adherence theme, fallowing-up all those who do not show good clinical treatment outcomes; the interdisciplinary approach. The study confirmed the expectation and the framework presupposition that the implementation in other health facilities will demand previous work with the institution and the professionals in order to promote the necessary opening to this approach, as discussed by the interviewed professionals.

As far as intervention conduction is concerned, the major difficulties mentioned by professionals referred to situations where they identified little availability on the part of the user to contact his life moment and context of life, or his trajectory as a person living with HIV. These same aspects particularly impaired the exploration and the decoding of the medication intake scenes. When scenes resource seemed to make sense to the user, this methodology allowed for an enhanced understanding of the situations which were discussed as well as the discovery of new alternatives to deal with the day by day of treatment.

Generally speaking, we can say that the intervention makes it possible to place the professional and the users as subjects of the intervention, assuming that the user, like the professional, possesses knowledge - of his life context, his quotidian, his personal, social and institutional resources to deal with his treatment - and that possible paths for a better relationship with the treatment should be built based on what he knows (contexts) and what he can manage (resources; Paiva, 2002).

In the ACCA approach, establishment of bond and dialogue between professional and user is a fundamental aspect for the success of intervention. We understand that, in each encounter, it is necessary to ponder over the difficulties per- ceived to the establishment of this dialogue and interaction, in such a way that users would not be considered individually responsible for failures. This is a point to be taken into account in a future intervention implementation.

We would like to stress that one of the most important differentials when discussing ACCA limits and potentials is the fact that it depends on unique interaction established between that user and the professional, as well as on the programmatic context where it will develop. Therefore, certain context and situations cannot be generalized as aspects that would be a priori associated with the success or failure of the intervention. Regarding the scenes resource, considered one of the most interesting and innovating practice resources according to experiences compiled in the field of prevention, the scenes methodology has been proved feasible in the most diverse social contexts, such as among the caiçara population (Bellenzani, Blessa, \& Paiva, 2008; A. O. Santos \& Paiva, 2007), the riverine communities in the Amazon (Benzaken, Garcia, Sardinha, Pedrosa, \& Paiva, 2007), the religious young people (Paiva, Garcia, et al., 2010) and the professionals responsible for their healthcare. Therefore, we understand that it is possible to deepen the discussion regarding difficulties perceived by the professionals in future intervention implementation and to devise paths to improve dialogue with users.

Broadly speaking, we consider that this experience reiterates the importance of establishing intervention protocols to guide the practice - which should not be mistaken, however, with a rigid standardization of actions. On the contrary, this proposal actually aims to encourage professionals' creativity in managing available resources, adapting them to the specificities of the relationship established with each user, without dismissing the particular context of each health facility. Knowledge on ACCA strategies and conceptions, for example, was provided not only through the training activities, but was also improved by supervision, which interacted with the practical knowledge of the professionals just as it happens in all the other approaches. A dialogic and continued education of professio- 
nals to enable stronger ownership of this or other approaches aiming to innovate health assistance inside SUS, should always promote high quality health assistance.

We would like to reaffirm that this research project context and, therefore, a necessarily more controlled environment in which the intervention was performed, even if it allows for the recognition of different potentialities and necessary improvements to ACCA, poses inevitable limits to our analysis, thus preventing us from knowing what other aspects may originate from an effective intervention implementation in health facilities routine. This study can only attempt to raise hypotheses regarding possible benefits resulting from the adoption of ACCA in healthcare facilities quotidian as well as in health professionals' training. Since these hypotheses referred to information obtained from the standpoint of the professionals, they should be combined with the analysis of the interviews with participating users and the recording of the encounters. A subsequent general analysis will enable a better understanding of this model of intervention.

In conclusion, we would like to stress that the critical reflection raised by the interviews with the professionals includes this approach in the field of approaches proposing the substitution of the notion of adherence by ideas expressing "collaboration" (Nemes, Santa-Helena, Caraciolo, \& Basso, 2009), "autonomy" (Williams, Rodin, Ryan, Grolnick, \& Deci, 1998), "empowerment" (Feste \& Anderson, 1995) and, especially "concordance" (Royal Pharmaceutical Society of Great Britain, 1997). In the same line, we find hypotheses stating that the appreciation of the quotidian life and its inter-subjective dynamics by the professional during the encounter with user can improve communication between both of them; that the understanding of the conveniences of treatment, from both parts, may lead to more feasible and compatible arrangements concerning the context and the quotidian of the person under treatment; that a shared responsibility for Care between the professional and the user is paramount to move towards the incorporation of a referential of rights, which has been appreciated in the healthcare practices (Gruskin \& Tarantola, 2008); and, finally, that the possibility for users and professionals to dialogue in the terms established by users may contribute to overcoming the paralysis often affecting both of them with a feeling that there are no paths left for a joint (re)construction of happiness projects.

\section{References}

Amico, K. R., Harman, J. J., \& Johnson, B. T. (2006). Efficacy of antiretroviral therapy adherence interventions: A research synthesis of trials, 1996 to 2004. Journal of Acquired Immune Deficiency Syndromes, 41(3), 285-297.

Ayres, J. R. C. M. (2001). Sujeito, intersubjetividade e práticas de saúde [Subject, intersubjectivity, and health practices]. Ciência \& Saúde Coletiva, 6(1), 63-72.

Ayres, J. R. C. M. (2004). Cuidado e reconstrução das práticas de saúde [Care and reconstruction in healthcare practices]. Interface - Comunicação, Saúde e Educação, 8(14), 73-92.

Ayres, J. R. C. M., Calazans, G., Saletti, H. C., Filho, \& França, I., Jr. (2006). Risco, vulnerabilidade e práticas de prevenção e promoção da saúde [Risk, vulnerability and practices of health prevention and promotion]. In G. W. S. Campos, M. C. S. Minayo, M. Akerman, M. Drummond Jr., \& Y. M. Carvalho (Orgs.), Tratado de Saúde Coletiva (pp. 375-417). Sao Paulo, SP: Hucitec.

Ayres, J. R. C. M., Paiva, V. S. F., \& França, I., Jr. (2011). From Natural History of Disease to Vulnerability: Changing concepts and practices in contemporary public health. In R. Parker \& M. Sommers (Eds.), Routledge handbook of global public health (pp. 98-107). New York: Routledge.

Ayres, J. R. C. M., Paiva, V. S. F., \& França, I., Jr. (2012). Conceitos e práticas de prevenção: Da história natural da doença ao quadro da vulnerabilidade e direitos humanos [Prevention concepts and practices: From natural history of disease to the context of vulnerability and human rights]. In V. S. F. Paiva, J. R. C. M. Ayres, \& C. M. Buchalla (Orgs.), Vulnerabilidade e direitos humanos: Prevenção e promoção da saúde (Vol. 1, pp. 71-94). Curitiba, PR: Juruá.

Bãban, A., \& Crãciun, C. (2007). Changing healthrisk behaviors: A review of theory and evi- 
dence-based interventions in health psychology. Journal of Cognitive and Behavioral Psychotherapies, 7(1), 45-67.

Basso, C. R. (2010). Avaliação da efetividade de uma intervenção psicossocial para melhorar a adesão do paciente à terapia antirretroviral da AIDS: Ensaio controlado aleatório utilizando monitoramento eletrônico [Evaluation of the effectiveness of a psychosocial intervention to improve patient adherence to antiretroviral therapy of AIDS: Randomized clinical trial using electronic monitoring] (Doctoral dissertation, Department of Preventive Medicine, Faculty of Medicine, University of Sao Paulo, Sao Paulo, SP, Brazil).

Basso, C. R., Santa-Helena, E. T., Caraciolo, J. M. M., Paiva, V. S. F., \& Nemes, M. I. B. (2012). Exploring ART intake scenes in a human rightsbased intervention to improve adherence: A randomized controlled trial. AIDS and Behavior. doi: 10.1007/s10461-012-0175-4. Retrieved May 15, 2012, from http://www.springerlink. com/content/a4860529p1g13127/

Bellenzani, R., Blessa, C. R. B., \& Paiva, V. S. F. (2008). Scripts in scene: HIV and sexual market in the context of tourism. Psicologia em Estudo, 13(4), 653-662.

Benzaken, A. S., Garcia, E. G., Sardinha, J. C. G., Pedrosa, V. L., \& Paiva, V. S. F. (2007). Community-based intervention to control STD/AIDS in the Amazon region, Brazil. Revista de Saúde Pública, 41(Supl. 2), 118-126.

Berger, P. L., \& Luckmann, T. (1987). A construção social da realidade: Tratado de Sociologia do Conhecimento [The social construction of reality: A treatise in the sociology of knowledge] (7. ed.). Petrópolis, RJ: Vozes.

Berkman, A., Garcia J., Munoz-Laboy, M., Paiva, V. S. F., \& Parker, R. (2005). A critical analysis of the Brazilian response to HIV/AIDS: Lessons for controlling and mitigating the epidemic in developing countries. American Journal Public Health, 95(7), 1162-1172.

Caraciolo, J. M. M. (2010). Caracterização das atividades para melhoria da adesão à TARV em serviços de saúde do SUS no estado de São Paulo [HAART adherence support provided by HIV/ AIDS outpatient clinics in Sao Paulo state, Brazil] (Master thesis, Department of Preventive Medicine, Faculty of Medicine, University of Sao Paulo, SP, Brazil).
Caraciolo, J. M. M., Santa-Helena, E. T., Basso, C. R., Souza, R. A., Silva, M. H., Adão, V. M., ...Nemes, M. I. B. (2009). Atividades para melhoria da adesão à TARV em serviços de saúde do SUS no estado de São Paulo, 2007 [Interventions to enhance HAART adherence in HIV/ AIDS health services in the state of Sao Paulo, Brazil, 2007]. Saúde e Sociedade, 18(Supl. 2), 79-83.

Dulmen, S., van., Sluijs, E., Dijk, L., van, Ridder, D., Heerdink, R., \& Bensing, J. (2007). Patient adherence to medical treatment: A review of reviews. BMC Health Services Research, 7, 55-67.

Feste, C., \& Anderson, R. M. (1995). Empowerment: From philosophy to practice. Patient Education and Counseling, 26(1), 139-144.

Freire, P. (1987). Pedagogia do oprimido [Pedagogy of the oppressed] (17. ed.). Rio de Janeiro, RJ: Paz e Terra.

Gagnon, J., \& Parker, R. (1995). Conceiving sexuality: Approaches to sex research in a postmodern world. New York: Routledge.

Glanz, K., Lewis, F. M., \& Rimer, B. K. (Eds.). (2002). Health behavior and health education: Theory, research and practice ( $3^{\text {rd }}$ ed.). San Francisco, CA: Jossey-Bass.

Goffman, E. (1975). A representação do eu na vida cotidiana [The presentation of self in everyday life]. Petrópolis, RJ: Vozes.

Goffman, E. (1980). Estigma: Notas sobre a manipulação da identidade deteriorada [Stigma: Notes on the management of spoiled identity] (3. ed.). Rio de Janeiro, RJ: Zahar.

Gruskin, S., \& Tarantola, D. (2008). Universal access to HIV prevention, treatment and care: Assessing the inclusion of human rights in international and national strategic plans. AIDS, 22(Suppl. 2), S123-S132.

Jung, C. G. (1985). Fundamentos de psicologia analitica [Analytical psychology: Its theory and practice] (3. ed.). Petrópolis, RJ: Vozes.

Kalichman, A., \& Diniz, S. (2009). AIDS treatment in Brazil: What kind of evidence do we need? Lancet, 374(969), 1066.

Mann, J., \& Tarantola, D. J. M. (1996). AIDS in the world II. New York: Oxford University Press.

Melchior, R., Nemes, M. I. B., Alencar, T. M. D., \& Buchalla, C. M. (2007). Desafios da adesão ao tratamento de pessoas vivendo com HIV/Aids 
no Brasil [Challenges of treatment adherence by people living with HIV/AIDS in Brazil]. Revista de Saúde Pública, 41(Supl. 2), 87-93.

Munro, S., Lewin, S., Swart, T., \& Volmink, J. (2007). A review of health behaviour theories: How useful are these for developing interventions to promote long-term medication adherence for TB and HIV/AIDS? BMC Health Services Research, 7, 104-119.

Nemes, M. I. B. (2009). Desenvolvimento da linha de pesquisa Qualiaids [Development of line of research Qualiaids] (Habilitation thesis, Department of Preventive Medicine, Faculty of Medicine of University of Sao Paulo, SP, Brazil).

Nemes, M. I. B., Castanheira, E. R. L., Santa-Helena, E. T., Melchior, R., Caraciolo, J. M. M., Basso, C. R., ...Ferraz, D. A. S. (2009). Adesão ao tratamento, acesso e qualidade da assistência em aids no Brasil [Treatment adherence, access and AIDS assistance quality in Brazil]. Revista da Associação Médica Brasileira, 55(2), 207-212.

Nemes, M. I. B., Qualiaids Team, \& CRT-DST/ AIDS-SP. (Coords.). (2009). Avaliação de tecnologias para melhoria da adesão do paciente ao tratamento antirretroviral da Aids [Assessment of technologies to improve patient's adherence to AIDS antiretroviral treatment] (Technical Report, PP-SUS 2006/2007, FAPESP N ${ }^{\circ}$ 2006/61277-6). São Paulo, SP: Fundação de Amparo à Pesquisa do Estado de São Paulo.

Nemes, M. I. B., Santa-Helena, E. T., Caraciolo, J. M. M., \& Basso, C. R. (2009). Assessing patient adherence to chronic diseases treatment: Differentiating between epidemiological and clinical approaches. Cadernos de Saúde Pública, 25(Suppl. 3), s392-s400.

Paiva, V. S. F. (2002). Sem mágicas soluções: A prevenção e o cuidado em HIV/AIDS e o processo de emancipação psicossocial [Beyond magical solutions: Prevention of HIV and Aids and the process of "psychosocial emancipation"]. Interface-Comunicação, Saúde e Educação, 6(11), 25-38.

Paiva, V. S. F. (2005). Analysing sexual experiences through 'scenes': A framework for the evaluation of sexuality education. Sex Education, 5(4), 345-359.

Paiva, V. S. F. (2006). Analisando cenas e sexualidades: A promoção da saúde na perspectiva dos direitos humanos [Analyzing scenes and sexualities: Health promotion in the human ri- ghts perspective]. In C. F. Cáceres, G. Careaga, T. Frasca, \& M. Pecheny (Orgs.), Sexualidad, estigma y derechos humanos: desafios para el acesso a la salud en América Latina (pp. 23-52). Lima, Peru: Facultad de Salud Pública y Administración Carlos Vidal Layseca, Universidad Peruana Cayetano Heredia.

Paiva, V. S. F. (2007). Gendered scripts and the sexual scene: Promoting sexual subjects among Brazilian teenagers. In R. Parker \& P. Aggleton (Eds.), Culture, society and sexuality: A reader $\left(2^{\text {nd }}\right.$ ed., pp. 427-442). New York: Routledge.

Paiva, V. S. F. (2008). A psicologia redescobrirá a sexualidade? [Will psychology rediscover sexuality?] Psicologia em Estudo, 13(4), 641-651.

Paiva, V. S. F. (2009). Prevenção PositHIVa? A abordagem psicossocial, emancipação e vulnerabilidade [PositHIVe Prevention? The psychosocial approach, emancipation and vulnerability]. In J. C. Raxach, I. Maksud, C. Pimenta, \& V. Terto Jr. (Orgs.), Prevenção positHIVa: Estado da arte: Vol. 8. Políticas públicas (pp. 33-49). Rio de Janeiro, RJ: Associação Brasileira Interdisciplinar de Aids.

Paiva, V. S. F. (2012a). Cenas da vida cotidiana: Metodologia para compreender e reduzir a vulnerabilidade na perspectiva dos direitos humanos [Scenes of everyday life: Methodology for understanding and reducing vulnerability in a human rights perspective]. In V. S. F. Paiva, J. R. C. M. Ayres, \& C. M. Buchalla (Orgs.), Vulnerabilidade e direitos humanos: Prevenção e promoção da saúde (Vol. 1, pp. 165-207). Curitiba, PR: Juruá.

Paiva, V. S. F. (2012b). A dimensão psicossocial do Cuidado [The psychosocial dimension of care]. In A. Segurado, G. Calazans, \& V. S. F. Paiva (Orgs.), Vulnerabilidade e direitos humanos: Prevenção e promoção da saúde (Vol. 2, pp. 4171). Curitiba, PR: Juruá.

Paiva, V. S. F., Ayres, J. R. C. M., \& Gruskin, S. (2010). Being young and living with HIV: The double neglect of sexual citizenship. In P. Aggleton \& R. Parker (Eds.), Routledge handbook of sexuality, health and rights (pp. 422-430). New York: Routledge.

Paiva, V. S. F., Garcia, J., Rios, L. F., Santos, A. O., Terto, V., Jr., \& Munõz-Laboy, M. (2010). Religious communities and HIV prevention: An intervention study using a human rights-based approach. Global Public Health, 5(3), 280-294. 
Parker, R., \& Aggleton, P. (1999). Culture, society and sexuality: A reader. New York: Routledge.

Parker, R., \& Aggleton, P. (2001). Estigma, discriminação e AIDS: Coleção ABIA: Vol. 1. Cidadania e direitos. Rio de Janeiro, RJ: Associação Brasileira Interdisciplinar de Aids.

Royal Pharmaceutical Society of Great Britain. (1997). From compliance to concordance: Toward shared goals in medicine taking. London: Author.

Rueda, S., Park-Wyllie, L. Y., Bayoumi, A. M., Tynan, A. M., Antoniou, T. A., Rourke, S. B., \& Glazier, R. H. (2006). Patient support and education for promoting adherence to highly active antiretroviral therapy for HIV/AIDS. Cochrane Database of Systematic Reviews, 3, CD001442. Retrieved March 31, 2012, from http://www. mrw.interscience.wiley.com/cochrane/clsysrev/ articles/CD001442/frame.html

Santos, A. O., \& Paiva, V. S. F. (2007). Vulnerabilidade ao HIV: Turismo e uso de álcool e outras drogas [Vulnerability to HIV: Tourism and the use of alcohol and other drugs]. Revista de Saúde Pública, 41(Supl. 2), 80-86.

Santos, M. A. (2010). Análise crítica de uma intervenção para melhoria da adesão do paciente vivendo com AIDS à terapia antirretroviral [Critical analysis of an intervention to the improvement of adherence of the patient living with AIDS to antiretroviral therapy] (Master thesis, Department of Social Psychology, Psychology Institute of University Sao Paulo, SP, Brazil).

Sato, L. (2005). Apresentação [Presentation]. In A. M. Rodrigues (Org.), Indivíduo, grupo e sociedade: Estudos de Psicologia Social (pp. 11-15). São Paulo, SP: Editora da Universidade de São Paulo.
Simon, W., \& Gagnon, J. H. (1984). Sexual scripts. Society, 22(1), 53-60.

Simoni, J. M., Frick, P. A., Pantalone, D. W., \& Turner, B. J. (2003). Antiretroviral adherence interventions: A review of current literature and ongoing studies. Topics in HIV Medicine, 11(6), 185-198.

Simoni, J. M., Pearson, C. R., Pantalone, D. W., Marks, G., \& Crepaz, N. (2006). Efficacy of interventions in improving highly active antiretroviral therapy adherence and HIV-1 RNA viral load. A meta-analytic review of randomized controlled trials. Journal of Acquired Immune Deficiency Syndromes, 43(Suppl. 1), S23-S35.

Teixeira, P. R., Paiva, V. S. F., \& Shimma, E. (Orgs.). (2000). Tá difícil de engolir? Experiências de adesão ao tratamento anti-retroviral em São Paulo [Is it difficult to swallow? Experiences of adherence to antiretroviral treatment in Sao Paulo]. São Paulo, SP: Núcleo de Estudos para a Prevenção da Aids, Universidade de São Paulo.

Williams, G. C., Rodin, G. C., Ryan, R. M., Grolnick, W. S., \& Deci, E. L. (1998). Autonomous regulation and long-term medication adherence in adult outpatients. Health Psychology, 17(3), 269-276.
Recebido: 26/06/2012

$1^{a}$ revisão: 03/09/2012 Aceite final: 25/09/2012 